Research Article

\title{
Optimal Hybrid Renewable Energy System: A Comparative Study of Wind/Hydrogen/Fuel-Cell and Wind/Battery Storage
}

\author{
Amevi Acakpovi $\left(\mathbb{D},{ }^{1}\right.$ Patrick Adjei, ${ }^{2}$ Nnamdi Nwulu $\left(\mathbb{D},{ }^{1}\right.$ and Nana Yaw Asabere $\mathbb{C}^{3}$ \\ ${ }^{1}$ Department of Electrical and Electronic Engineering Science, University of Johannesburg, Johannesburg, South Africa \\ ${ }^{2}$ Department of Marine Electrical/Electronic Engineering, Regional Maritime University, Accra, Ghana \\ ${ }^{3}$ Department of Computer Science, Accra Technical University, Accra, Ghana
}

Correspondence should be addressed to Amevi Acakpovi; acakpovia@gmail.com

Received 27 July 2020; Revised 22 November 2020; Accepted 5 December 2020; Published 15 December 2020

Academic Editor: Ping-Feng Pai

Copyright (c) 2020 Amevi Acakpovi et al. This is an open access article distributed under the Creative Commons Attribution License, which permits unrestricted use, distribution, and reproduction in any medium, provided the original work is properly cited.

\begin{abstract}
This paper performs a technoeconomic comparison of two hybrid renewable energy supplies (HRES) for a specific location in Ghana and suggests the optimal solution in terms of cost, energy generation capacity, and emissions. The two HRES considered in this paper were wind/hydrogen/fuel-cell and wind/battery storage, respectively. The necessity of this study was derived from the rise and expansion of hybrid renewable energy supply in a decentralised network. The readiness to embrace these new technologies is apparently high, but the best combination for a selected location that brings optimum benefits is not obvious and demands serious technical knowledge of their technical and economic models. In the methodology, an analytical model of energy generation by the various RE sources was first established, and data were collected about a rural-urban community in Doderkope, Ghana, to test the models. HOMER software was used to design the two hybrid systems based on the same load profiles, and results were compared. It turns out that the HRES 1 (wind/hydrogen/fuel-cell) had the lowest net present cost (NPC) and levelized cost of electricity (COE) over the project life span of 25 years. The energy reserve with the HRES 2 (wind/battery storage) was huge compared to that with the HRES 1, about $270 \%$ bigger. Furthermore, with respect to the emissions, the HRES 2 was environmentally friendlier than the HRES 1 . Even though the battery storage seems to be more cost-effective than the hydrogen fuelcell technology, the latter presents some merits regarding system capacity and emission that deserve greater attention as the world looks into more sustainable energy storage systems.
\end{abstract}

\section{Introduction}

Transition to renewable energy usage is a global and unprecedent trend in the twenty-first century. Recently, G20 pushed for the effective and substantial integration of renewable energy in countries' electricity demands [1]. Africa is also confronting the revolution age of renewable energies penetrating the electricity market. In West Africa and Ghana, particularly, some few technologies including solar, wind, and recently fuel-cell technologies are emerging.

The integration of renewable energy in Ghana is supported by policy documents including the investment-focused Renewable Energy Master Plan which optimistically target a renewable energy production of 2,500 MW by 2030 . The Renewable Energy Act, 2011 (Act 832), further provides avenues to encourage investment into renewable energy in Ghana which has brought a lot of independent power producers in the electricity market in Ghana.

Solar energy is a very promising source of renewable energy in Ghana [2]. The potential of solar is huge in Ghana with an average irradiation level ranging from 4.5 to $6 \mathrm{kWh} / \mathrm{m}^{2}$ per day. There has been increasing investment in solar energy in Ghana recently, and the trend continues to grow considerably. Similarly, the interest in wind energy is also growing. Ghana has embarked on its first wind farm, the 225 MW Ayitepa wind farm to be hosted in the Ningo Prampram region.

On the other hand, fuel cell is an emerging technology as illustrated by the number of companies embracing the technology in Ghana [3]. It helps generate electricity from the chemical energy of a fuel, usually hydrogen, in the 
presence of oxygen. The technology presents some advantages over the conventional battery that make it more attractive. Unlike batteries, fuel cell does not need a continuous supply of hydrogen and oxygen to sustain their chemical reaction. Fuel cell can continuously generate electricity, provided there is supply of hydrogen and oxygen. The fuel, in this case, hydrogen is generated through several means among which a preferred method is electrolysis using a proton-exchange membrane or polymer-electrolyte membrane (PEM). Electrolysis is simply the process of splitting water into hydrogen and oxygen using an electrolyser.

Furthermore, hybrid energy systems involving wind energy generally require a storage device owing to the fact that wind resource is highly intermittent, and therefore the production of energy based on wind suffers the same intermittency. At some period where electricity might not be needed, the production is high, and at other time when the demand is high, the production is rather low or insignificant. All these factors explain the need of storage to make wind energy generation more comprehensive and responsive to electricity demand.

Usually, batteries have been used to accumulate excess production and discharge later to satisfy electricity demand. Batteries add up to the installation and maintenance cost of wind energy generation while also emitting some level of toxic gases. On the other hand, combining fuel cell and wind may yield interesting efficiency and may further challenge the battery storage considering cost, maintenance, capacity of generation, and emission as criteria. In the wind/fuel-cell configuration, the excess energy generated by the wind turbine is use to supply the electrolysis process that generate hydrogen and store them in a tank. The hydrogen is later fed to the fuel cell in the presence of oxygen for the electricity generation process to continue.

The hybrid wind/battery storage and the hybrid wind/ hydrogen/fuel-cell systems present several advantages and disadvantages that deserve a thorough analysis to determine the optimal one for a specific location. This form of comparative analysis has not been documented with enough literature in the past. This paper aims at shedding light on the reality by selecting the optimal HRES considering cost, maintenance, capacity, and emission criteria.

The rest of the paper is organized as follows: Section 2 presents the literature review, Section 3 presents the methodology, Section 4 presents the results and interpretations, and finally Section 7, presents the conclusion.

\section{Literature Review}

This section presents a review of existing hybrid energy systems involving wind, battery, hydrogen, and fuel cell and discusses their benefits and drawbacks. Specifically, hybrid solar/wind and battery systems, hybrid wind/battery systems, and hybrid wind/hydrogen/fuel-cell systems were discussed. Again, the methodologies used to design hybrid energy systems were discussed with special consideration to existing software used to optimize them.
A considerable number of previous studies considered the optimal design, challenges, and limitations of solar/wind and battery storage hybrid system [4-8]. Such hybrid systems combine solar and wind generation with some storage to ensure power availability and reliability. Solar and wind resources are not permanently generated throughout the day, so their combination leads to some complementarities and consequently requires a lesser energy storage capacity. Studies on some particular systems were looking into optimal design consideration with regard to net present cost and levelized cost of electricity $[5,9,10]$. Similarly, the authors in [11] investigated a self-developed algorithm, based on observation of state of charge, required size and number of solar array, wind turbine, and battery capacity needed for a stand-alone system. Again, reliability was also investigated, and this system proves to be economically viable in most cases. On the other hand, wind/battery systems seem simpler in terms of complexity of design with promising efficiencies.

Alternatively, studies on wind/battery hybrid systems are primarily concerned with best energy management practice especially with regard to the planning of battery storage. For instance, Zhang and Li [12] dealt with the dilemma of planning the battery storage setpoint for the longer horizon or not and resolve it with an optimization problem, well posed. The fact is that wind resource is highly dynamic and unpredictable. Therefore, the design of the battery storage must be such that power supply to the load remains constant. Similarly Singh and Chandra [13] explain the design constraints of a wind/battery system that charges batteries during peak demands and releases the charge during low or zero generation, thus maintaining a constant generation. Singh and Chandra [13] explored a more advanced and realtime energy management system of a wind/battery hybrid system termed as model predictive control (MPC). The MOC guarantees optimal economic profit by dynamically optimizing generation output based on two variables known as daily number of cycles (DNC) and depth of discharge (DOD). The efficiency of wind/battery hybrid system, however, has not been compared with other combinations using fuel cell which is emerging with promising benefits.

Fuel cell has recently been involved in many hybrid systems and yielded robust systems with high capacity and efficiency. Iqbal [14]; Khan and Iqbal [15]; and Samaniego et al. [16] considered the reliable design of wind/hydrogen/ fuel-cell hybrid energy system to supply constant electricity continuously for one year by simulating different operation schemes of the fuel cell with the TRNSYS 15 software. ElShatter et al. [17] and Nelson et al. [18] also considered a similar design, but this time, they add a PV to the hybrid system, thus raising the complexity of design to a higher level. Nelson et al. [18] further performed comparison with a wind/battery storage using a graphical interface under MATLAB software. Khan and Iqbal [15] and Sawle et al. [19] further considered a more complex system that combines wind/hydrogen/fuel cell and capacitor bank design and found it very suitable for off-grid power generation in remote communities. 
It is necessary to understand the fact that various methods have been used in the design of these hybrid systems to get the optimum values. Many studies conducted their optimization analysis considering criteria like loss of power supply probability (LPSP) [20] which explains the probability of a load being supplied continuously. Other studies were focused on levelized cost of electricity. Advanced $\mathrm{AI}$ techniques like adaptive neurofuzzy inference system (ANFIS) were employed in modelling solar and wind resources. Some popularly known heuristic algorithm including particle swarm optimization, Tabu search, and simulated annealing (SA) have been intensively used to solve the design optimization problem. Moreover, advanced metaheuristic optimization techniques were also employed including improved harmony search (IHS), improved particle swarm optimization (IPSO), and artificial bee swarm optimization (ABSO) as illustrated by Maleki and Pourfayaz [21]. Ahmadi and Abdi [22] innovated with a method that was unusual in dealing with the same challenge of optimum design of hybrid energy system, namely, the Big Bang-Big crunch algorithm.

A number of software were used in the literature reviewed to design and optimize HRES. HOMER which stands for Hybrid Optimization Model for Electrical Renewables has been intensively used and has an attractive user interface and procedures that facilitate the design and optimization activities. HOGA which stands for Hybrid Optimization by Genetic Algorithm was also used to simulate hybrid energy systems and sometimes compared to optimization solutions developed by individual authors. MATLAB and TRNSYS were equally used to model nonlinearities of some components and simulate the overall HRES.

In summary, previous studies dealt intensively with different forms of HRES but failed to make substantive comparison but failed to make substantive comparison among them, in order to find in order to find the most appropriate system that suits a particular location at a time. At the exception of [18] which made an attempt to compare the effectiveness of two different HRES, namely, a wind/PV/ fuel cell and conventional system with battery, most of the studies seem to underrate this particular aspect. There are rigorous criteria based on cost, reliability of supply, system capacity, and emission that should determine at a point in time which system is preferable and most suitable for a particular location. In the case of this paper, a rigorous comparison was conducted between the conventional wind/ battery storage and wind/hydrogen/fuel cell after designing properly the system component for a same load. The analysis is conducted with the HOMER software which happens to be one of the most popular software used to design HRES.

\section{Methodology}

This paper proposes a comparative analysis of two hybrid renewable energy configuration and storage systems for a residential community in Ghana. The first hybrid renewable energy system (HRES) scenario is wind/hydrogen/fuel-cell from water electrolysis and the second HRES scenario is a configuration of wind and battery storage. The proposed system analyses the technoeconomic potential of the hydrogen fuel cell and battery storage from wind energy technology. This section modelled, simulated, and optimized the two hybrid configurations using HOMER software and further compared their performance based on metrics such as net present cost (NPC), cost of energy (COE), and amount of generated energy to determine the optimal solution for the residential community.

3.1. Hybrid Renewable Energy System (HRES) Scenarios. The analysis of the hybrid renewable energy system presented in this study was categorised as HRES scenario 1 and HRES scenario 2. The HRES scenario 1 is the configuration of wind and hydrogen fuel cell from water electrolysis, and the HRES scenario 2 is a configuration of wind as a primary generator and battery storage system.

3.1.1. HRES Scenario One. The HRES scenario is made up of a wind turbine, a hydrogen fuel-cell generator, a hydrogen tank for hydrogen storage, and an electrolyser to split water into hydrogen and oxygen gas. The dispatch strategy used in this configuration allows the primary generator (wind turbine) to meet the electrical load demand, and excess energy is used by the electrolyser to produce hydrogen. During low and very high wind periods (wind below turbine cut-in and cut-out speed), the generated power may be insufficient for the load demand. Therefore, the fuel-cell supplies the shortage. The block diagram of HRES scenario 1 is illustrated in Figure 1.

3.1.2. HRES Scenario Two. The HRES scenario 2 configuration is made of a wind turbine, an AC/DC converter, and a battery storage system. The dispatch strategy employed in this hybrid configuration allows the wind turbine to serve the electrical demand satisfactorily. The generated excess energy is used to charge the battery, while the wind turbine remains the primary generator. When the wind turbine is unable to serve the electrical load demand, the battery storage is switched to "discharge mode" to supply the shortage. The configuration is shown in Figure 2.

3.2. Load Profiling. A remote off-grid rural-urban community in Doderkope, south-eastern part of Ghana, with about 100 households (350 dwellers) and some few commercial offices and a small-scale irrigation facility for the majority farming activities has been considered. A semiresidential load profile with a daily consumption of $25.21 \mathrm{kWh} / \mathrm{d}$ and a peak load of $5.35 \mathrm{~kW}$ is proposed for this study. The commercial offices and the small-scheme irrigation scheme (DC pump $1.45 \mathrm{kWh} /$ day and peak load of $0.71 \mathrm{~kW}$ ) get their electricity from diesel generators installed in their premises. Some individuals depend on small diesel generators for electricity, while a majority of them cannot access electricity from the grid, due to their remote location from the national grid. The commercial offices and the irrigation scheme get their diesel supply from tanker trucks 


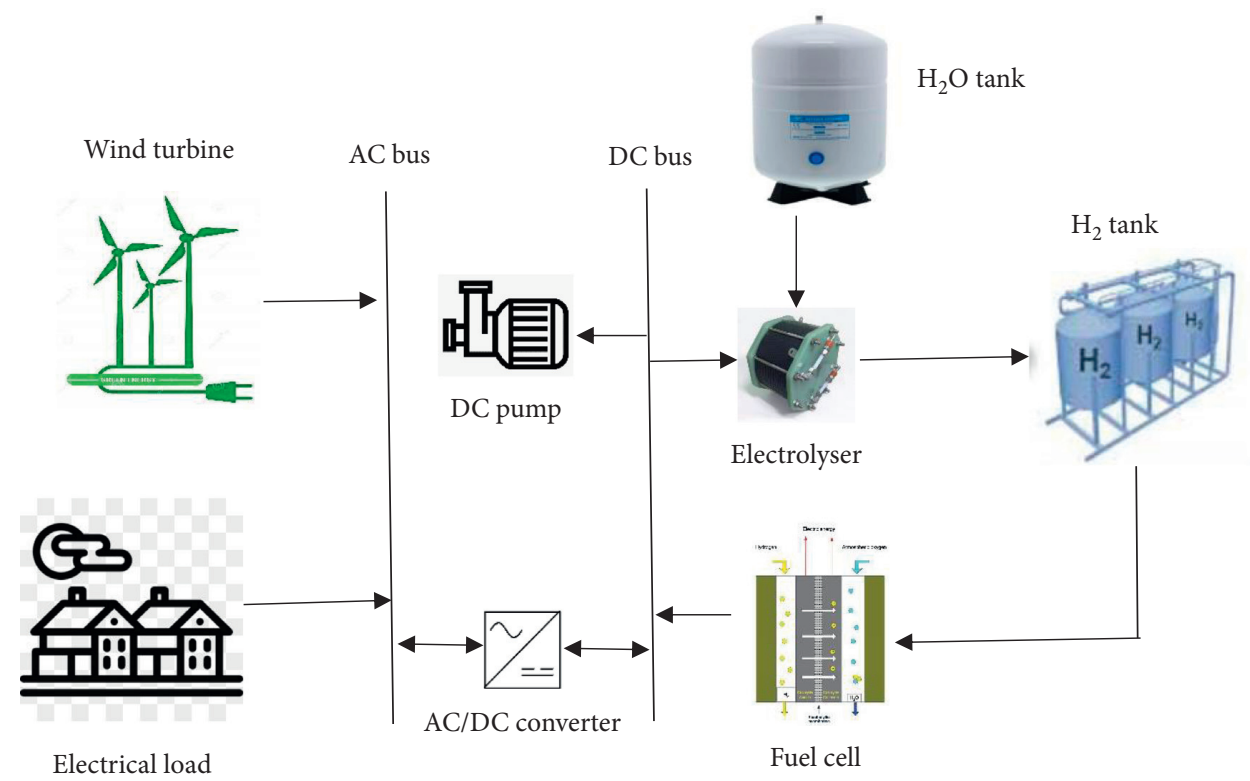

Figure 1: HRES scenario 1 block diagram.

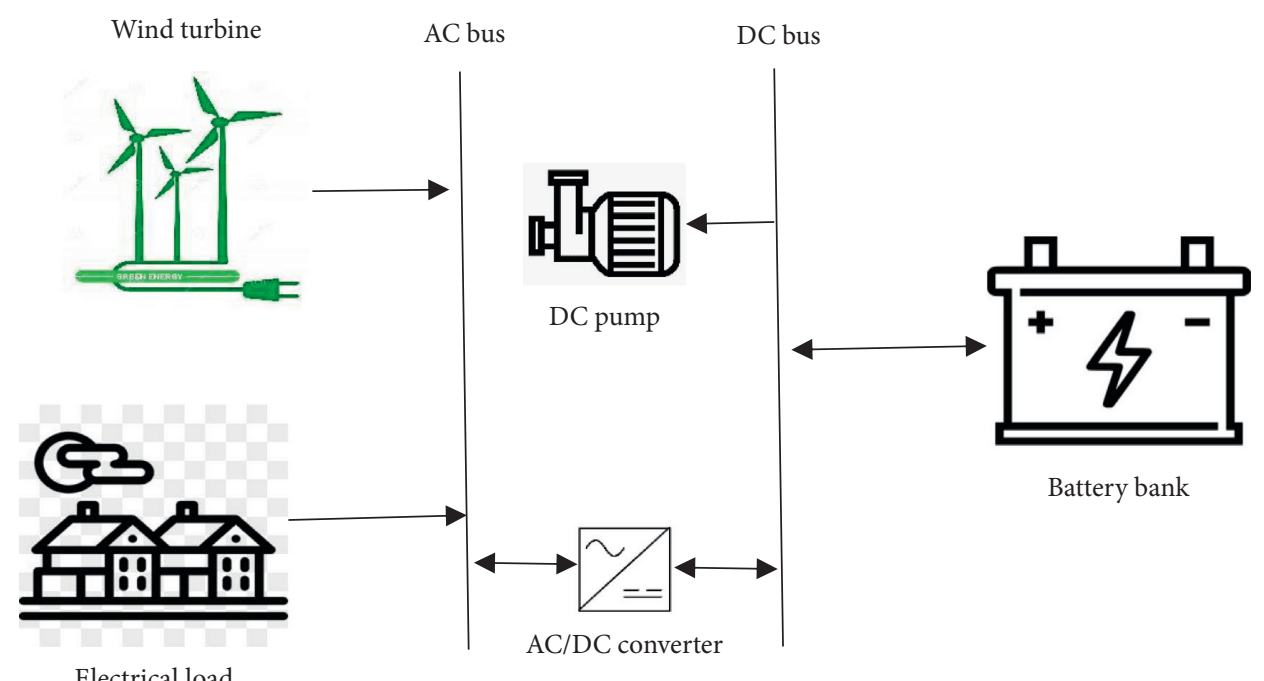

FIgURE 2: HRES scenario 2 block diagram.

which adds up the overall cost of the diesel fuel for their diesel generators. The diesel fuel delivered to the community is assumed to cost one dollar fifty cent (US\$ 1.50 ) per liter after adding the storage and cost of transportation. The map capture and load profile of the remote community as extracted from HOMER are presented in Figure 3.

3.3. Wind Resources Assessment of the Community. In order to extract the energy of the wind for electricity production, the wind resource of the community was extracted from the National Aeronautics and Space Administration Weather database hosted by the National Renewable Energy Laboratory website [23]. In wind energy, wind speed distribution is often modelled using probability distribution functions. The most common probability functions used for wind speed distribution are Weibull distribution function [24] illustrated as follows:

$$
f(v)=\left(\frac{k}{c}\right) \cdot\left(\frac{v}{c}\right)^{k-1} \cdot \exp \left(-\left(\frac{v}{c}\right)^{k}\right)
$$

where $k$ is the Weibull shape parameter, $c$ is Weibull scale parameter, and $f(v)$ is the probability of observing the wind speed $v$. The Weibull parameters $c$ and $k$ are calculated in this paper using the maximum likelihood method because it is the most recommended method for fitting a Weibull distribution in wind energy analysis. The likelihood function $L_{v}$ is given as follows [24]: 


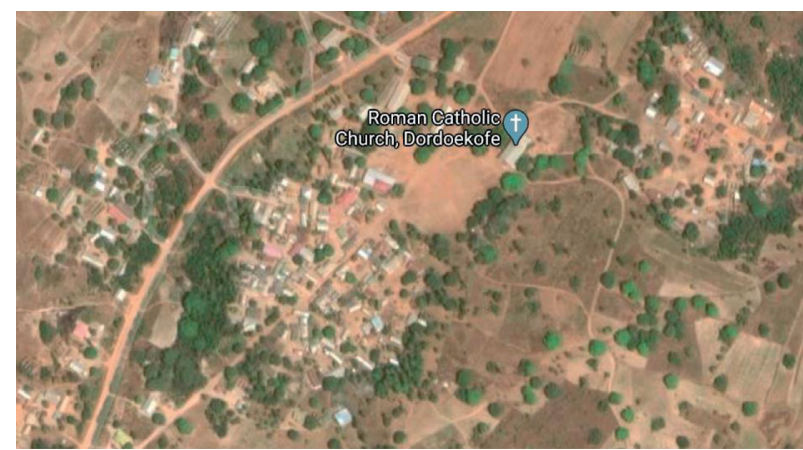

(a)

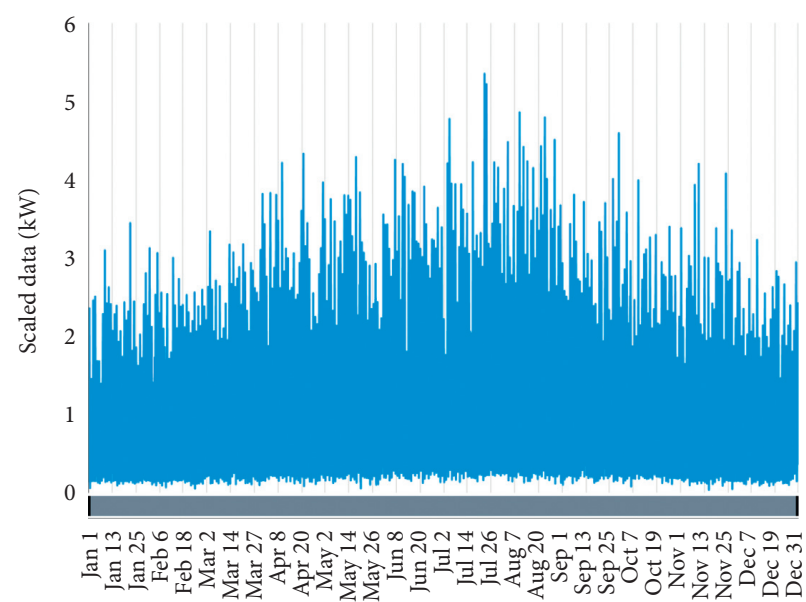

(b)

Figure 3: (a) Remote community in the south-eastern part of Ghana. (b) Daily load profile of the selected community at Doderkope.

$$
\begin{aligned}
L_{v} & =\prod_{i=1}^{N} F\left(v_{i}\right), \\
L_{v} & =\prod_{i=1}^{N}\left(\frac{k}{c}\right) \cdot\left(\frac{v_{i}}{c}\right)^{k-1} \cdot \exp \left[-\left(\frac{V_{i}}{c}\right)^{k}\right] .
\end{aligned}
$$

The maximum likelihood is the maximization of $\ln \left(L_{V}\right)$ which is expanded to

$$
\ln \left(L_{V}\right)=\sum_{i=1}^{N} \text { in }-k \sum_{1=1}^{N} \ln c+(k-1) \sum_{i=1}^{N} \ln V_{i}-\sum_{i=1}^{N}\left(\frac{V_{i}}{c}\right)^{k} .
$$

$\ln \left(L_{V}\right)$ is maximum when

$$
\begin{array}{r}
\left\{\frac{\partial \operatorname{In}\left(L_{v}\right)}{\partial k}=0, \frac{\partial \operatorname{In}\left(L_{v}\right)}{\partial c}=0,\right. \\
\left\{\sum_{i=1}^{N}\left\{\frac{1}{k}+\left[1-\left(\frac{v_{i}}{c}\right)^{k}\right] \ln \left(\frac{v_{i}}{c}\right)\right\}=0\right. \\
\left\{\sum_{i=1}^{N}\left(\frac{k}{c}\right) \cdot\left[-1+\left(\frac{v_{i}}{c}\right)^{k}\right]=0 .\right.
\end{array}
$$

The solution to this system leads to a set of nonlinear equations.

$$
\begin{gathered}
\left\{\sum_{i=1}^{N}\left\{\frac{1}{k}+\left[1-\left(\frac{v_{i}}{c}\right)^{k}\right] \ln \left(\frac{v_{i}}{c}\right)\right\}=0,\right. \\
\left\{\sum_{i=1}^{N}\left(\frac{k}{c}\right) \cdot\left[-1+\left(\frac{v_{i}}{c}\right)^{k}\right]=0 .\right.
\end{gathered}
$$

where $v_{i}$ is the value of wind speed at time $i$ and $N$ is the total number of wind speed data. (5) is solved using iterative techniques as used by [25].
3.4. Extrapolation of Wind Speed and Power Density Using Weibull Parameters. Wind turbines are usually installed at heights higher than $10 \mathrm{~m}$ which is the height of most anemometers in weather stations including the wind speed data from the NASA weather station. For this reason, wind speeds at wind turbine heights above $10 \mathrm{~m}$ must be extrapolated to appropriate heights used for wind power production. An advantage of Weibull distribution is that Weibull parameters can be obtained at different heights. This study used the Weibull parameters to extrapolate wind speed data measured at $10 \mathrm{~m}$ to a hub height of $80 \mathrm{~m}$. The Weibull parameters at height $h$ is given by $[26,27]$

$$
\begin{aligned}
& c(h)=c_{0} \cdot\left(\frac{h}{h_{0}}\right)^{n}, \\
& k(h)=k_{0} \cdot \frac{1-0.088 \ln \left(h_{0} / 10\right)}{1-0.088 \ln (h / 10)},
\end{aligned}
$$

where $C_{0}$ and $k_{0}$ represent Weibull scale and shape parameter at height $h$ and reference height $h_{0}$ and $n$ is the roughness index defined by [27]

$$
n=\frac{0.37-0.088 \ln \left(C_{0}\right)}{1-0.088 \ln (h / 10)} \text {. }
$$

Wind power density can be calculated by using the Weibull probability function as follows:

$$
P(v(h))=\frac{1}{2} \cdot \rho \cdot c(h)^{3} \cdot \Gamma\left(\frac{k(h)+3}{k(h)}\right) .
$$

$\Gamma$ is the gamma function defined as

$$
\Gamma(x)=\int_{0}^{\infty} t^{(x-1)} \cdot \exp (-t) \mathrm{d} t
$$

and $\rho$ is the air density at the study area in $\mathrm{kg} / \mathrm{m}^{3}$. 


\subsection{Modelling of System Components}

3.5.1. Wind Turbine. For a wind turbine, if the wind speed exceeds the cut-in speed, the wind turbine generator starts generating power. If the wind speed is equal or exceeds the rated wind speed of the wind turbine, the generator will generate constant power. However, if the wind speed exceeds the cut-out speed of the wind turbine, the wind turbine stops generating to protect the wind turbine and component from damage. The power generated from each wind turbine at time $t$ is estimated by

$$
\begin{gathered}
P_{\mathrm{wt}}(t)=\left\{\begin{array}{l}
0, \\
P_{r-\mathrm{wt}}, \frac{v(t)-v_{\text {cut-in }}}{v_{r}-v_{\text {cut-in }}}, \\
P_{r-\mathrm{wt}},
\end{array}\right. \\
\text { Subject to } v(t) \leq v_{\text {cut-in }} \text { OR } v(t) \geq v_{\text {cut-out }}, \\
v_{\text {cut-in }}<v(t)<v_{r}, \\
v_{r}<v(t)<v_{\text {cut-out }},
\end{gathered}
$$

where $v(t)$ is the wind speed at time $t(\mathrm{~m} / \mathrm{s}), P_{r-w t}$ is the rated power of the wind turbine in $\mathrm{kW}$, and $V_{\text {cut-out }}, V_{\text {cut-in }}$, and $V_{r}$ are the cut-out speed, cut-in and rated speed of the wind turbine $(\mathrm{m} / \mathrm{s})$, respectively. If the number of wind turbines is $N_{\text {wt }}$, then the total produced power is modelled as

$$
P_{w \text { total }}(t)=N_{\mathrm{wt}} \times P_{\mathrm{wt}}(t)
$$

Table 1 shows the technical specifications of the selected wind turbine. The turbine has a low starting wind speed which falls well within the wind speed of the study area. The life span of the turbine is also within the project lifetime. This means that the wind turbine will not be replaced before the end of the project, reducing the overall replacement cost.

Additionally, Figure 4 displays the turbine power curve which is an important criterion in the selection of appropriate wind turbine for the wind regime of the study area. The power curve shows the expected electricity production with the corresponding wind speed. The cut-in speed of the turbine is $2.5 \mathrm{~m} / \mathrm{s}$ with the wind turbine power output of $0.19 \mathrm{~kW}$ at $4 \mathrm{~m} / \mathrm{s}$. The wind turbine reaches its rated capacity of $10 \mathrm{~kW}$ at $15 \mathrm{~m} / \mathrm{s}$. The wind turbine safety system reduces the speed of the blades at $20 \mathrm{~m} / \mathrm{s}$ and finally cuts out the wind turbine speed at $24 \mathrm{~m} / \mathrm{s}$.

3.6. Fuel Cell (FC)/Electrolyser. In the wind/fuel-cell hybrid system, the storage system works under the following condition: if the power generated by the wind is greater than the load demand at time $t$, then the electrolyzer will be allowed to generate hydrogen to fill the hydrogen tank. The amount of hydrogen to be stored in the hydrogen tank is estimated as follows:

$$
E_{\text {stor }}(t)=E_{\text {stor }}(t-1)+\left[\left(E_{\mathrm{wt}}(t) \times \eta_{\text {inv }}^{2}\right)-\frac{E_{\text {Load }}(t)}{\eta_{\text {inv }}}\right] \times \eta_{\text {Elect }} \text {, }
$$

where $E_{\text {stor }}(t)$ and $E_{\text {stor }}(t-1)$ are the energy stored in the hydrogen tanks at time $t$ and $t-1$ in $\mathrm{kWh}$, respectively, $E_{\text {load }}$ is the electrical load demand in $\mathrm{kWh}, \eta_{\text {inv }}$ is the efficiency of the inverter, and $\eta_{\text {Elect }}$ is the efficiency of the electrolyser.

When the electrical load demand on the wind generator is insufficient, the fuel cell is used to supply the additional demand needed by the electrical load. Therefore, the amount of hydrogen stored in the hydrogen tanks at hour $t$ is calculated according to the following equation:

$$
E_{\text {stor }}(t)=E_{\text {stor }}(t-1)-\frac{\left[\left(E_{\text {Load }}(t) / \eta_{\text {inv }}\right)-\left(E_{\mathrm{wt}}(t) \times \eta_{\text {inv }}^{2}\right)\right]}{\eta_{\mathrm{FC}} \times \eta_{\text {inv }}},
$$

where $\eta_{\mathrm{FC}}$ is the efficiency of the fuel cell which is estimated using the following equation:

$$
\eta_{\mathrm{FC}}=\frac{3.6\left(P_{\mathrm{Gen}}\right)}{\left(F_{0}+F_{1} P_{\mathrm{Gen}}\right) L H V_{\text {Hydrogen }}} .
$$

To guarantee the condition for hydrogen to be used by the fuel-cell generator, the fuel curve is adjusted to follow the hydrogen produced by the electrolyser based on the following equation:

$$
F=F_{0} Y_{\mathrm{Gen}}+F_{1} P_{\mathrm{Gen}}
$$

The fuel-cell generation is simulated for full optimization throughout the year. This means the fuel-cell generation will assume periods of low wind turbine generation, but it will adjust the power output to maintain 100\% hydrogen fraction.

3.7. Water Electrolysis. Water electrolysis is the process of splitting water into hydrogen and oxygen gas by passing direct current through water using electrodes. Renewable hydrogen can be produced by using RE resource through water electrolysis described as an emerging green RE technology. The electrolysis process is expressed as follows:

$$
\mathrm{H}_{2} \mathrm{O} \longrightarrow 2 \mathrm{H}_{2}+\mathrm{O}_{2}, \Delta \Delta H^{o}=286 \mathrm{~kJ} / \mathrm{mol} \text { (at } 25^{\circ} \mathrm{C}, 1 \mathrm{bar} \text { ) }
$$

The block diagram in Figure 5 illustrates the setup for hydrogen production.

3.8. Battery Storage System. Due to the intermittent nature of wind resources, battery storage systems have become a common part of most hybrid RE configurations. The battery storage system changes in response to the hybrid system configuration. The state of charge of the battery is obtained as follows: when the total output of the wind turbine is greater than the load demand, the battery is switched to charge state using the excess energy produced by the wind turbine to charge. The amount of charge of the battery at time $t$ is estimated as follows: 
TABLE 1: Wind turbine specifications.

Rated power

Maximum output power

Generator

Blade quantity

Rotor blade diameter

Start-up wind speed

Rated wind speed

Survival wind speed

Controller

Safety system

Noise

Temperature range

Warranty
Turbine weight

Design lifetime

$10 \mathrm{~kW}$
$13 \mathrm{~kW}$
AC
3 glass fiber blades
$8 \mathrm{~m}(26.2 \mathrm{ft})$
$2.5 \mathrm{~m} / \mathrm{s}(5.6 \mathrm{mph})$
$15 \mathrm{~m} / \mathrm{s}(22.3 \mathrm{mph})$
$24 \mathrm{~m} / \mathrm{s}(133.1 \mathrm{mph})$
PLC with touch screen
Yaw control, electrical brake, and hydraulic brake
$420 \mathrm{~kg}(925.9 \mathrm{lbs})$
$45 \mathrm{db}(\mathrm{A})$ at $5 \mathrm{~m} / \mathrm{s}$
$-20^{\circ} \mathrm{C}$ to $+50^{\circ} \mathrm{C}$
25 years
Standard 5 years

Refer [28].
Wind turbine power curve

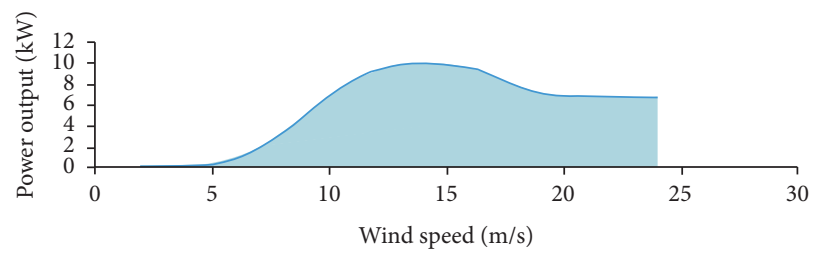

Figure 4: Power curve of the selected wind turbine [28].

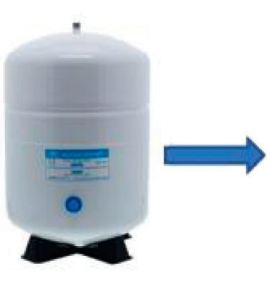

Water tank

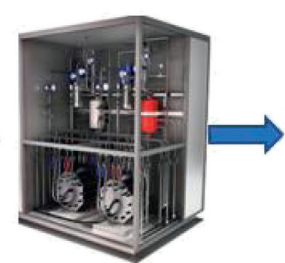

Electrolyser

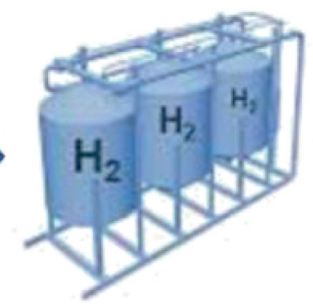

Hydrogen tank

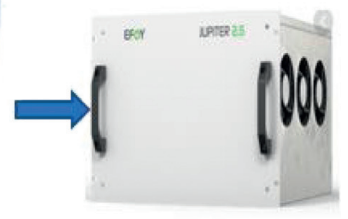

PEM fuel cell

FIgURE 5: Block diagram of fuel cell/electrolyser.

$$
\begin{aligned}
E_{\text {Batt }}(t)= & E_{\text {Batt }}(t-1) \times(1-\sigma) \\
& +\left[\left(E_{\mathrm{wt}}(t) \times \eta_{\text {inv }}^{2}\right)-\frac{E_{\text {Load }}(t)}{\eta_{\text {inv }}}\right] \times \frac{\eta_{\mathrm{BC}}}{\eta_{\text {inv }}},
\end{aligned}
$$

where $E_{\text {Batt }}(t)$ and $E_{\text {Batt }}(t-1)$ are the amount of charge of the battery storage at time $t$ and $t-1$ in $\mathrm{kWh}$, respectively, $\eta_{\text {inv }}$ is inverter efficiency, $\eta_{\mathrm{BC}}$ is the charge efficiency of the battery storage system, and $\sigma$ is the hourly self-discharge rate.

When the total output of the wind turbine is less than that of the demand, the battery switches to discharge state and supplies the shortage.

\subsection{Cost and Technical Details of the HRES}

3.9.1. Economic Parameters for HRES. In HOMER, the annual interest rate is a necessary input parameter. The annual interest rate can be estimated as follows:

$$
i=\frac{i_{0}-f}{1+f},
$$

where $i$ is interest rate. $i_{0}$ is the nominal interest rate, and $f$ is the inflation rate per year.

In this study, an assumed nominal interest rate of $9.00 \%$ and inflation rate of $14.5 \%$ were used for the real interest rate estimation. 
3.9.2. Levelized Cost of Energy (LCOE). The levelized cost of Energy as defined by HOMER is the average cost of useful electrical energy produced by the HRES. The levelized cost of energy can be estimated using the the following equation:

$$
\mathrm{LCOE}=\frac{\mathrm{NPV} \times \mathrm{CRF}}{E_{\mathrm{ann}, \text { served }}},
$$

where LCOE is the levelized cost of energy in US\$, NPV is the net present value, $E_{\text {ann,served }}$ is $s$ the annual electric load served, and CRF is capital recovery factor. The value of the CRF can be estimated using the following equation:

$$
\operatorname{CRF}(i, N)=\frac{i(1+i)^{N}}{(1+i)^{N}-1}
$$

3.9.3. Net Present Value (NPV). NPV is defined as the current value of initial and operating cost of the HRES over the lifetime of the system. It can also be assumed to be the life-cycle cost of the system. The lifetime of the HRES in this study is 25 years. The NPV is therefore an important output parameter in determining the economic feasibility of any HRES. HOMER ranks RE systems based on the NPV of the system. The following equation can be used to find the NPV of the HRES:

$$
\mathrm{NPV}=C_{\text {in }}+C_{\text {rep }}+C_{O \& M}-\mathrm{PV}_{\text {sal }} \text {, }
$$

where $C_{\text {in }}$ is the Initial capital cost, $C_{\text {rep }}$ is the replacement cost, $C_{O \& M}$ is the operation and maintenance cost, and $\mathrm{PV}_{\text {sal }}$ is the salvage present value of the HRES.

The initial capital cost of the HRES $\left(C_{i n}\right)$ is determined using the following equation:

$$
\begin{aligned}
C_{\mathrm{in}}= & \left(\mathrm{WT}_{p} \times P_{r-\mathrm{wt}} \times N_{\mathrm{wt}}\right)+\left(E_{\mathrm{Batt}} \times B_{p}\right)+\left(\mathrm{Inv}_{p} \times \mathrm{Inv}_{r}\right) \\
& +\left(\mathrm{FC}_{p} \times \mathrm{FC}_{r}\right)+\left(\mathrm{ELZ}_{p} \times \mathrm{ELZ}_{r}\right)+\left(H_{2 T p} \times H_{2 T r}\right),
\end{aligned}
$$

where $\mathrm{WT}_{p}$ is the price of wind turbine per $\mathrm{kW}(\$ / \mathrm{kW}), E_{\mathrm{Batt}}$ is the battery capacity $(\mathrm{kWh}), B_{p}$ is the price of battery $(\$ / \mathrm{kWh}), \mathrm{Inv}_{p}$ is the inverter price $(\$ / \mathrm{kWh}), \mathrm{Inv}_{r}$ is inverter capacity $(\mathrm{kW}), \mathrm{FC}_{p}$ is the fuel-cell price $(\$ / \mathrm{kW}), \mathrm{FC}_{r}$ is the fuel-cell capacity in $\mathrm{kW}, \mathrm{ELZ}_{p}$ is the price of the electrolyser $(\$ / \mathrm{kW}), \mathrm{ELZ}_{r}$ is the capacity of the electrolyser in $\mathrm{kW}, H_{2 T p}$ is the price of hydrogen tank $(\$ / \mathrm{kg})$, and $H_{2 T r}$ is the hydrogen tank capacity in $\mathrm{kg}$.

The cost of replacement of the HRES is estimated using the following equation $[29,30]$ :

$$
C_{\text {rep }}=\sum_{i=1}^{N_{\text {rep }}}\left(C_{\mathrm{RC}} \times C_{U} \times\left(\frac{1+i}{1+r}\right)^{N \times\left(i / N_{\text {rep }}+1\right)}\right),
$$

where $N_{\text {rep }}$ is the number of replacements, $C_{\mathrm{RC}}$ is the capacity of the replacement unit ( $\mathrm{kW}$ for wind turbine, inverter, fuel cell, and electrolyser; kWh for battery storage system and $\mathrm{kg}$ for the hydrogen tank). $C_{U}$ is the unit replacement cost $(\$ / \mathrm{kW}$ for wind turbine, fuel cell, electrolyser, and inverter, $\$ / \mathrm{kWh}$ for the battery, and $\$ / \mathrm{Kg}$ for the hydrogen tank). $N_{\text {rep }}$ is the number of replacement component over the life span of the project.

$C_{O \& M}$ is the operation and maintenance cost of the HRES which is expressed in the following equation [31]:

$$
\begin{aligned}
& C_{O \& M}=C_{O \& M 0} \times\left(\frac{1+i}{r-i}\right) \times\left(1-\left(\frac{1+i}{1+r}\right)^{N}\right), \quad r \neq i, \\
& C_{O \& M}=C_{O \& M 0} \times N, \quad r=i .
\end{aligned}
$$

The present salvage value of the component in the HRES is determined using the following equation $[32,33]$ :

$$
\mathrm{PV}_{\mathrm{sal}}=\sum_{i=1}^{N_{\text {rep }+1}} V_{\text {sal }} \times\left(\left(\frac{1+r}{1+r}\right)^{N \times\left(i / N_{\text {rep }+1}\right)}\right),
$$

where $V_{\text {sal }}$ is the salvage value of the HRES components.

\section{Optimizing the Components of the HRES}

The selection of components and their sizes for building a reliable HRES was done through optimization. The optimization consisted in minimizing the net present cost (NPC) and maximizing the reliability of the HRES, which is estimated based on the loss power supply probability (LPSP), while preserving the percentage of excess energy (PEE) needed to charge battery or for hydrogen production. Five input variables, namely:

(i) Number of wind turbines, $N_{\text {wt }}$

(ii) Number of electrolyzers, $N_{\text {ELZ }}$

(iii) Number of fuel cells, $N_{\mathrm{FC}}$

(iv) Number of hydrogen tanks, $N_{H 2 T}$

(v) Number of batteries, $N_{\text {Batt }}$

were considered and controlled during the optimization exercise. The objective $Q$ is introduced in equation (26) as follows:

$$
\begin{aligned}
& Q=\operatorname{mini} . \mathrm{NPC}\left(N_{\mathrm{wt}}, N_{\mathrm{ELZ}}, N_{\mathrm{FC}}, N_{H 2 T}, N_{\text {Batt }}\right), \\
& \text { subject to the following constraints, } \\
& 0 \leq N_{\mathrm{wt}} \leq N_{\mathrm{PV}}^{\max }, \\
& 0 \leq N_{\mathrm{ELZ}} \leq N_{\mathrm{ELZ}}^{\max }, \\
& 0 \leq N_{\mathrm{FC}} \leq N_{\mathrm{FC}}^{\max }, \\
& 0 \leq N_{H 2 T} \leq N_{H 2 T}^{\max }, \\
& 0 \leq N_{H 2 T} \leq N_{H 2 T}^{\max }, \\
& 0 \leq N_{\text {Batt }} \leq N_{\text {Batt }}^{\max }, \\
& 0 \leq N_{\text {Batt }} \leq N_{\text {Batt }}^{\max } .
\end{aligned}
$$

From equation (27), the problem can be considered as a linear optimization problem. MATLAB software has an inbuilt function to handle linear optimization problem known as the "linprog" function. The optimization problem was solved using the linprog function of MATLAB, and the result led to the technical details and cost of the RE system as 
shown in Table 2. Additionally, the project lifetime is assumed to be 25 years, and there is no government subsidy on RE systems.

4.1. Operation of the Hybrid Renewable Energy System (HRES). HOMER considers RE resources availability, load, cost, and technical details of components of an HRES while performing its technoeconomic analysis. For each hybrid combination, the energy flow in the components is calculated by comparing the load demand to the energy produced. HOMER software further considers capital cost, replacement cost, and maintenance cost to determine the most feasible configuration which supplies the load demand. The operation procedure of the HRES is as follows.

\section{Result and Interpretation}

5.1. Wind Characteristics of the Study Area. The wind resource of the study area is presented in Table 3. The wind resource data were extracted from NREL database, a feature of the HOMER software. The wind resource was measured at a $10 \mathrm{~m}$ height above ground. Since wind speed increases with height, the wind data were extrapolated at $80 \mathrm{~m}$ of the wind turbine hub height using equation (6) with a roughness index of 0.14. A roughness index of 0.14 is used for Doderkope because the area is characterized by agricultural land with some houses and estimated 8 meters tall sheltering hedgerows with distances of approximately 500 meters [27]. The results of the extrapolation are presented in Figure 6.

5.2. Economic Comparison of the HRES Scenarios. In this paper, the two off-grid standalone HRES configurations, being compared, are set to 25 years with a nominal interest rate of $9 \%$ and inflation rate of $14.5 \%$ considered. The COE, NPC, initial capital, and operating capital were used as tool to measure the economic performance of the two HRES scenarios. The capital cost refers to the initial installed cost of the various components of the HRES which include installation area, wiring, protective components, and cost of skilled man power labour. All these components have a lifetime, and therefore when the lifetime is over before the system's lifetime, they must be replaced. The lifetime cost of the two HRES is shown in Figure 7, where HRES 2 has the highest replacement cost compared to HRES 1 . HRES 1 had the highest operation and maintenance cost which is almost equal to the replacement cost of HRES 2. HRES 2 has the highest salvage cost compared to HRES 1, and HRES 1 has the highest initial capital cost.

The details of the NPC for the HRES scenarios, as presented in Figures 8 and 9, indicate that, in HRES 1, the storage system accounted for $64 \%$ of the NPC followed by the wind turbine (34\%) and the control strategy (4\%); whereas in HRES 2, the wind turbine generator accounted for $52 \%$ of the NPC followed by the storage system and control strategy, respectively. The cost component of the inverter for HRES 1 and 2 remained constant since the same size and number of inverters were the optimized size for each of HRES.
TABLE 2: HRES component parameters.

\begin{tabular}{|c|c|}
\hline Component parameters & \\
\hline $\begin{array}{l}\text { Interest rate, } i \\
\text { Project lifetime, } n\end{array}$ & $\begin{array}{c}16.550 \\
25 \text { years }\end{array}$ \\
\hline $\begin{array}{l}\text { Fuel cell } \\
\text { Rated power } \\
\text { Efficiency } \\
\text { Life span (hours) } \\
\text { Capital cost (US\$) } \\
\text { Replacement cost (US\$) } \\
\text { Maintenance cost }\left(\mathrm{C}_{\mathrm{mtn}}\right) \text { (US\$) }\end{array}$ & $\begin{array}{c}10 \mathrm{~kW} \\
70 \% \\
50,000.00 \\
2,000.00 \\
2,000.00 \\
10.00\end{array}$ \\
\hline $\begin{array}{l}\text { Electrolyser } \\
\text { Rated power } \\
\text { Efficiency } \\
\text { Life span } \\
\text { Capital cost/kW } \\
\text { Replacement cost } \\
\text { Maintenance cost (US\$) }\end{array}$ & $\begin{array}{c}10 \mathrm{~kW} \\
85 \% \\
15 \text { years } \\
1,000.00 \\
1,000.00 \\
20.00\end{array}$ \\
\hline $\begin{array}{l}\text { Hydrogen tank } \\
\text { Capital cost (US\$/Kg) } \\
\text { Replacement cost } \\
\text { Maintenance cost (US\$) } \\
\text { Capacity of tank } \\
\text { Life span } \\
\end{array}$ & $\begin{array}{c}200.00 \\
200.00 \\
20.00 \\
100 \mathrm{~kg} \\
25 \text { years } \\
\end{array}$ \\
\hline $\begin{array}{l}\text { Power inverter/converter } \\
\text { Rated power } \\
\text { Efficiency } \\
\text { Life span } \\
\text { Capital cost US\$/kW } \\
\text { Replacement cost (US\$) } \\
\text { O\&M cost }\end{array}$ & $\begin{array}{c}10 \mathrm{~kW} \\
96 \% \\
25 \\
600.00 \\
600.00\end{array}$ \\
\hline $\begin{array}{l}\text { Battery } \\
\text { Nominal capacity } \\
\text { Charge efficiency } \\
\text { Discharge efficiency } \\
\text { Capital cost (US\$)/pc } \\
\text { Life span } \\
\text { DOD } \\
\text { Nominal voltage }\end{array}$ & $\begin{array}{c}6.6 \mathrm{kWh} \\
85 \% \\
100 \% \\
6,915.00 \\
10 \\
48 \mathrm{~V}\end{array}$ \\
\hline
\end{tabular}

TABle 3: Wind resource assessment of Doderkope

\begin{tabular}{lcc}
\hline Month & Wind speed $(\mathrm{m} / \mathrm{s})$ at $10 \mathrm{~m}$ & Wind speed $(\mathrm{m} / \mathrm{s})$ at $80 \mathrm{~m}$ \\
\hline January & 3.72 & 4.98 \\
February & 3.99 & 5.34 \\
March & 4.05 & 5.42 \\
April & 3.6 & 4.82 \\
May & 3.18 & 4.25 \\
June & 3.25 & 4.35 \\
July & 4.47 & 5.98 \\
August & 4.63 & 6.19 \\
September & 4.6 & 6.15 \\
October & 3.71 & 4.96 \\
November & 3.96 & 5.30 \\
December & 3.33 & 4.46 \\
\hline
\end{tabular}

The COE, operating cost, initial capital, and NPC which are performance-measuring tools for the two HRES are presented in Table 4. HOMER chooses an HRES based on the lowest NPC and COE. The most feasible HRES based on 


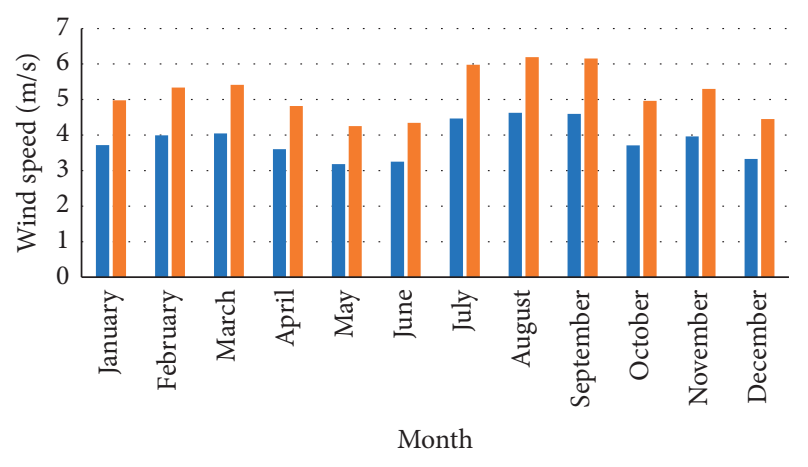

- Wind speed at $10 \mathrm{~m}$

- Wind Speed at $80 \mathrm{~m}$

Figure 6: Monthly wind speed of Doderkope at $10 \mathrm{~m}$ and $80 \mathrm{~m}$.

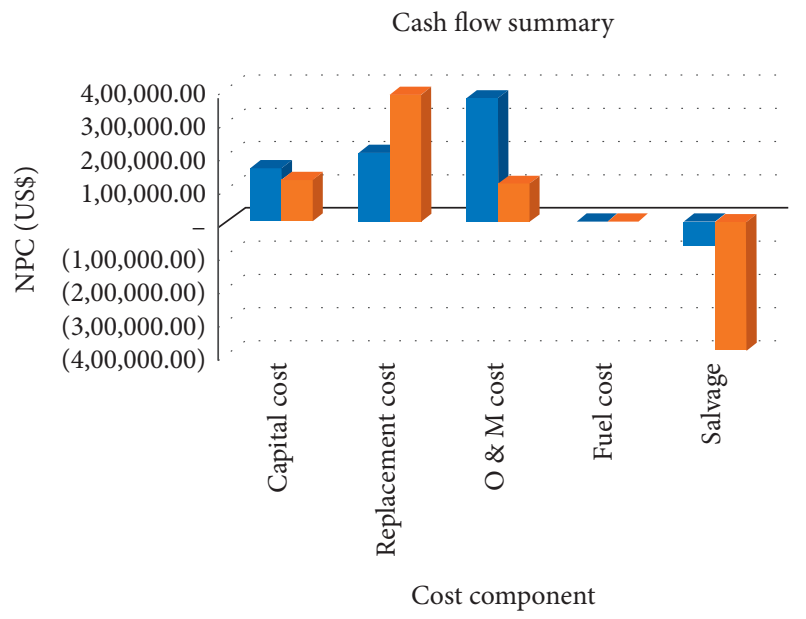

- HRES 1

- HRES 2

FIGURE 7: HRES scenario lifetime cost comparison.

COE and NPC is HRES 2 with US\$ 0.28 and US\$ 23,876.34 as COE and NPC, respectively.

5.3. Technical Comparison of HRES Scenarios. The technical feasibility of HRES depends highly on the performance of the $\mathrm{RE}$ resources and the ability of the $\mathrm{RE}$ components to transform RE resources into useful electrical power. The performance parameter of the HRES scenarios in this study is the electrical production of each component of the HRES.

The daily average wind turbine power generation of HRES 1 and HRES 2 for each year is presented in Figures 10 and 11, respectively. As can be seen from Figure 10, the total annual energy production of HRES 1 is from the wind turbine and the fuel cell, accounting for $36.7 \%$ of the annual production. Both HRES recorded high and low electrical production in the months of July, August, and September with moderately high electrical production in the months of October to April.

The annual electric production for both HRES scenarios 1 and 2 is presented in Table 5. The annual electric

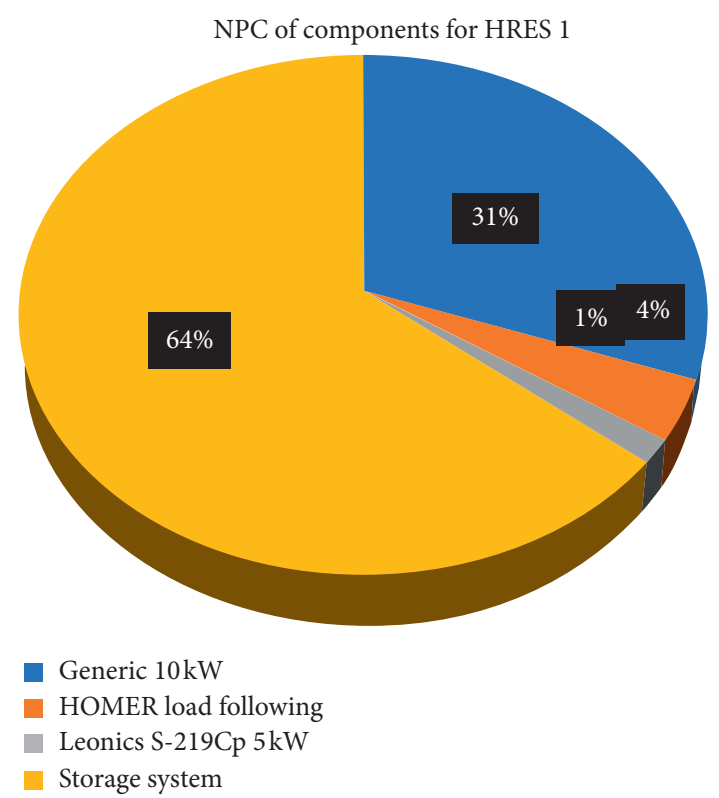

FIgURE 8: Details of NPC by component for HRES 1.

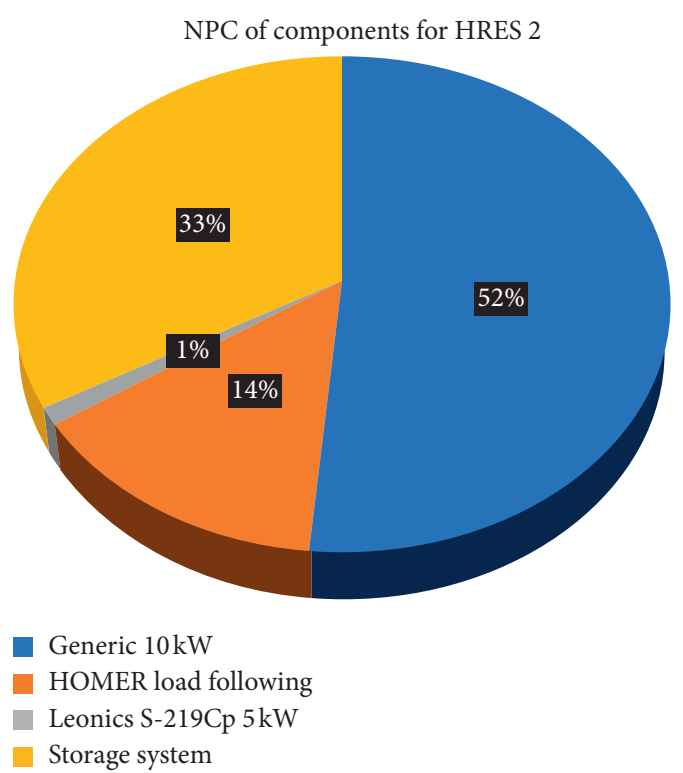

Figure 9: Details of NPC by components of HRES 2.

production for HRES 1 is twice higher than the annual electric production for HRES 2, and this is expected because the main generator (wind Generator) in HRES 2 is $10 \mathrm{~kW}$, which is half of the size of generator in HRES 1 . However, HRES 1 had $15.5 \%$ of the annual electric production as excess electricity, whereas HRES 2 annual excess electricity was $56.7 \%$. The hydrogen tank autonomy which measures the ratio of the hydrogen to electric load was 4802 hours which is $54.81 \%$ of the hours it served the electrical load. The battery energy storage like the hydrogen storage operated for 81 hours in the year which is $0.9 \%$ of hours operated in a year. 
TABLE 4: Economic comparison of HRES scenarios.

\begin{tabular}{lcc}
\hline Cost component & HRES 1 & HRES 2 \\
\hline NPC (US\$) & $672,374.74$ & $236,876.34$ \\
Initial capital (US\$) & $161,000.00$ & $127,150.00$ \\
Operating capital (US\$)/yr & $4,877.00$ & 763.43 \\
COE (US\$) & 1.12 & 0.28 \\
\hline
\end{tabular}

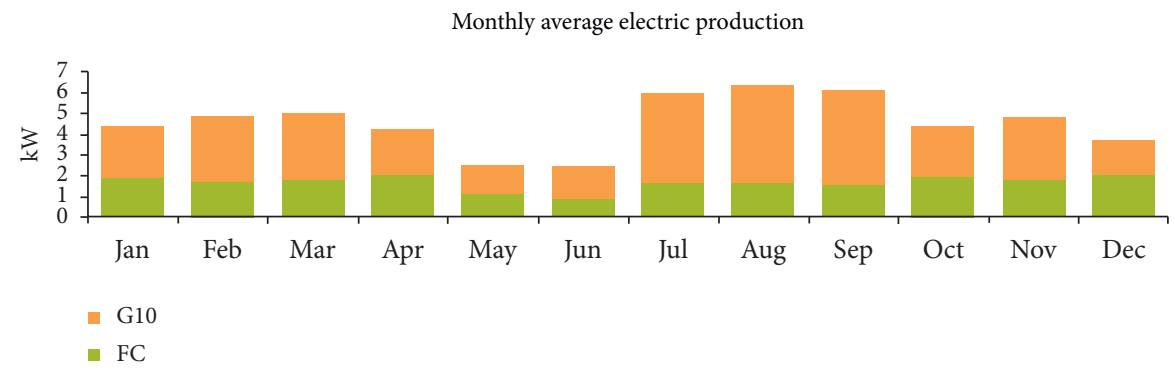

FIGURE 10: Monthly average electric production by HRES 1.

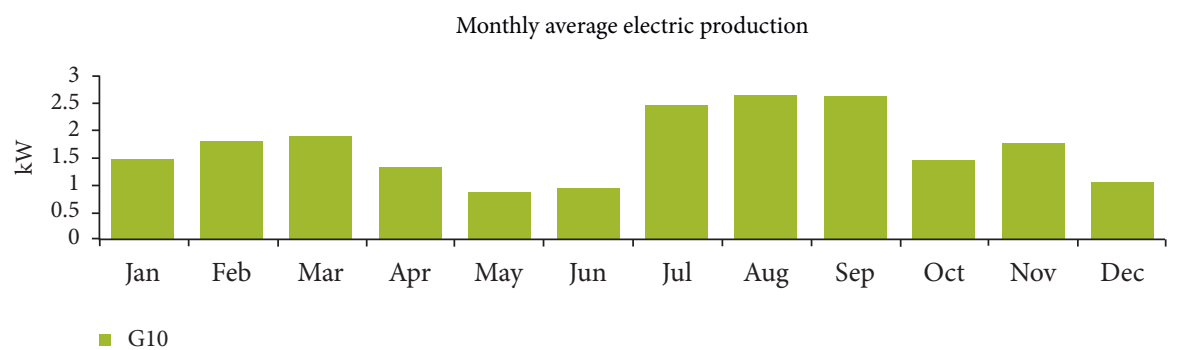

FIGURE 11: Monthly average electric production by HRES 2.

TABLE 5: Technical comparison of HRES scenarios.

\begin{tabular}{lcc}
\hline Parameters & HRES 1 & HRES 2 \\
\hline Total power generated (kWh/yr) & 39,805 & 14,739 \\
AC primary load served (kWh/yr) & 5,246 & 5,430 \\
DC load served (kWh/yr) & 501 & 517 \\
Excess electricity (kWh/yr) & 4,932 & 8,355 \\
Unmet electric load (kWh/yr) & 334 & 134 \\
Fuel-cell electric production (kWh/yr) & 14,611 & N/A \\
Hydrogen energy storage capacity (kWh) & 3,333 & N/A \\
Tank autonomy (hrs.) & 4,802 & N/A \\
Fuel-cell operation hours (hrs/yr) & 5,843 & N/A \\
Battery autonomy (hrs.) & N/A & 81 \\
Battery energy storage (kWh/yr) & N/A & 2.444 \\
\hline
\end{tabular}

5.4. Sensitivity Comparison of HRES Scenarios. A sensitivity analysis reveals how sensitive the output of the HRES scenarios is to change the input. In the sensitivity analysis, HOMER performs multiple optimization each using a set of different input assumptions. In this study, the sensitivity variables that were considered were Doderkope scaled average load and DC pump scaled average load. It is anticipated that the load demand of Doderkope will increase in future; therefore, a sensitivity analysis is a performance tool that is needed to measure how the HRES will deal with these anticipations. The anticipated increase in load demand of
Doderkope will have effect on the technoeconomic parameters of the HRES. After performing multiple optimization of each sensitivity variable input, the obtained results are presented in Figures 12-17. The results show the scaled average load of Doderkope and scaled average DC Pump load with their respective impact on NPC, COE, and quantity of wind generators.

In Figures 12 and 13, it can be seen that, for HRES 1, as the load increases, the NPC of the system increases, but at the highest load anticipated, NPC reduces. Similarly, for HRES 2, an increase in the load yielded an increase in the NPC of the system.

Moreover, in Figures 14 and 15, COE decreased with an increase in the electric load demand for HRES 1, while COE for HRES 2 decreases as the electric load demand increased. On the other hand, at the highest anticipated load demand, COE increased from its immediate previous cost i.e., \$0.277, $\$ 0.214$, and $\$ 0,246$.

Finally, Figures 16 and 17 show the quantity of wind turbine generators that were needed as the load demand increases. In HRES 1 (Figure 16), as the load demand increases, the quantity of wind turbine also increases while maintaining constant, the highest electric load anticipated. In Figure 17, which represents HRES 2, the quantity of wind generators was constant despite the increasing demand till the highest anticipated load was 


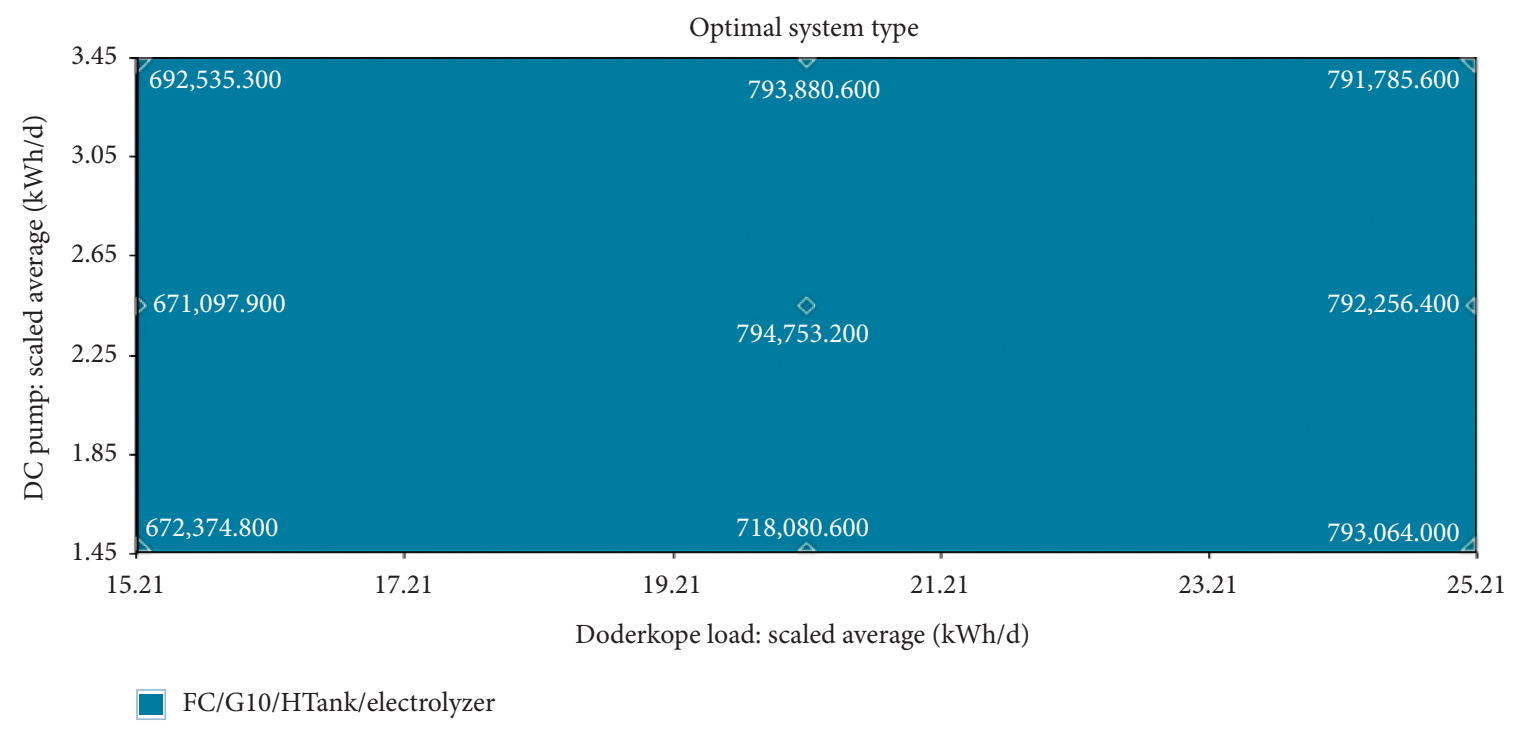

FIGURE 12: Sensitivity NPC output for HRES 1.

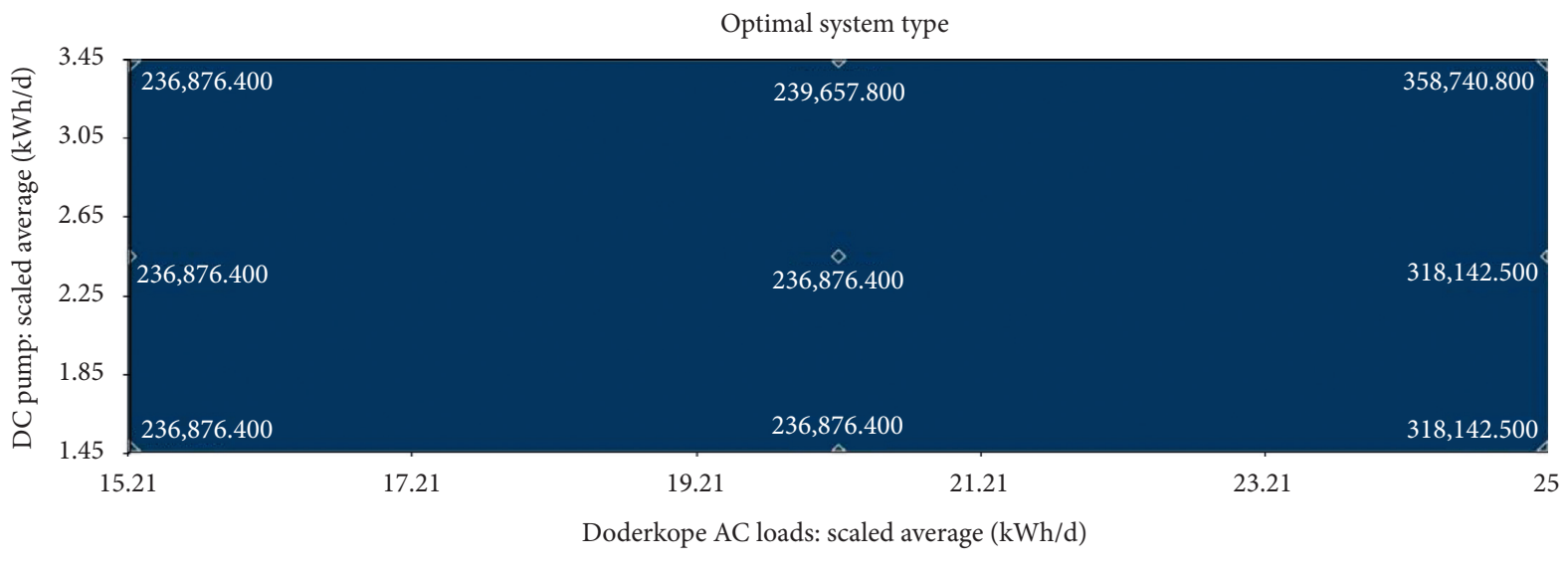

G10/Dis6.6

FIgURE 13: Sensitivity (NPC) of HRES 2.

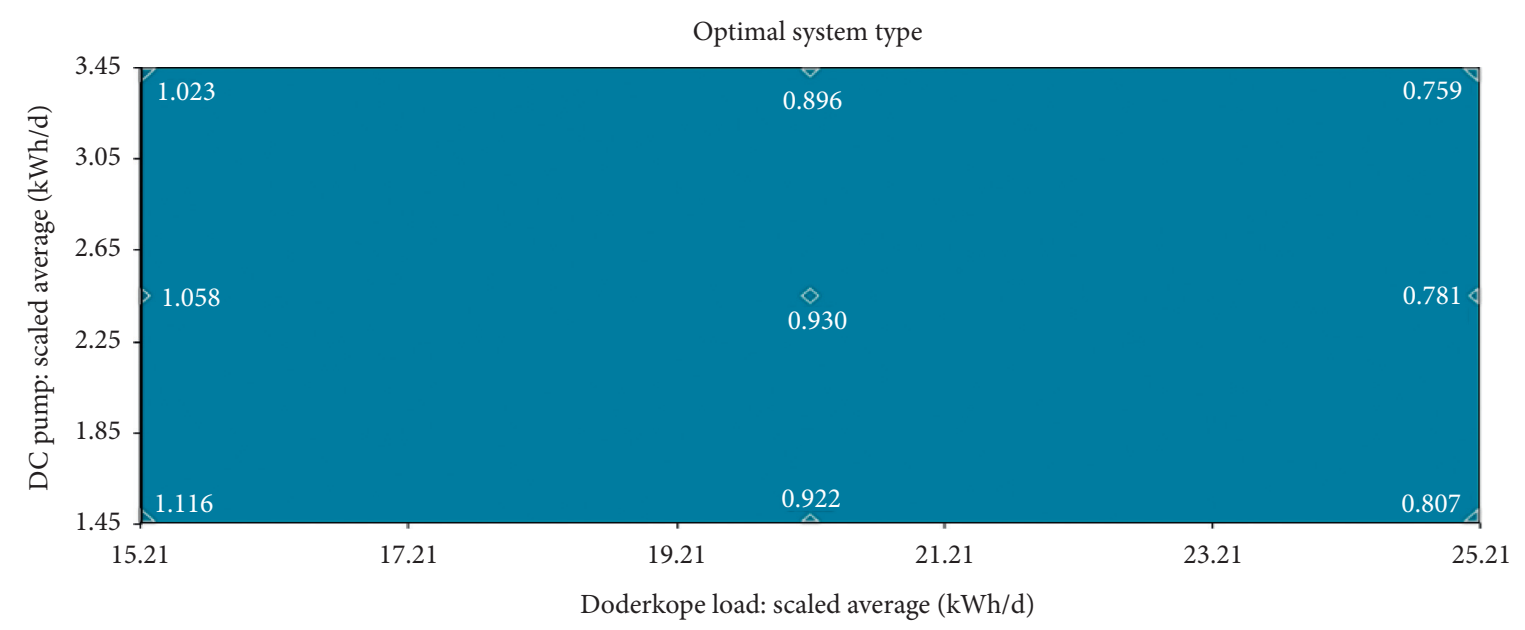

FC/G10/HTank/electrolyzer

Figure 14: Sensitivity (COE) of HRES 1. 


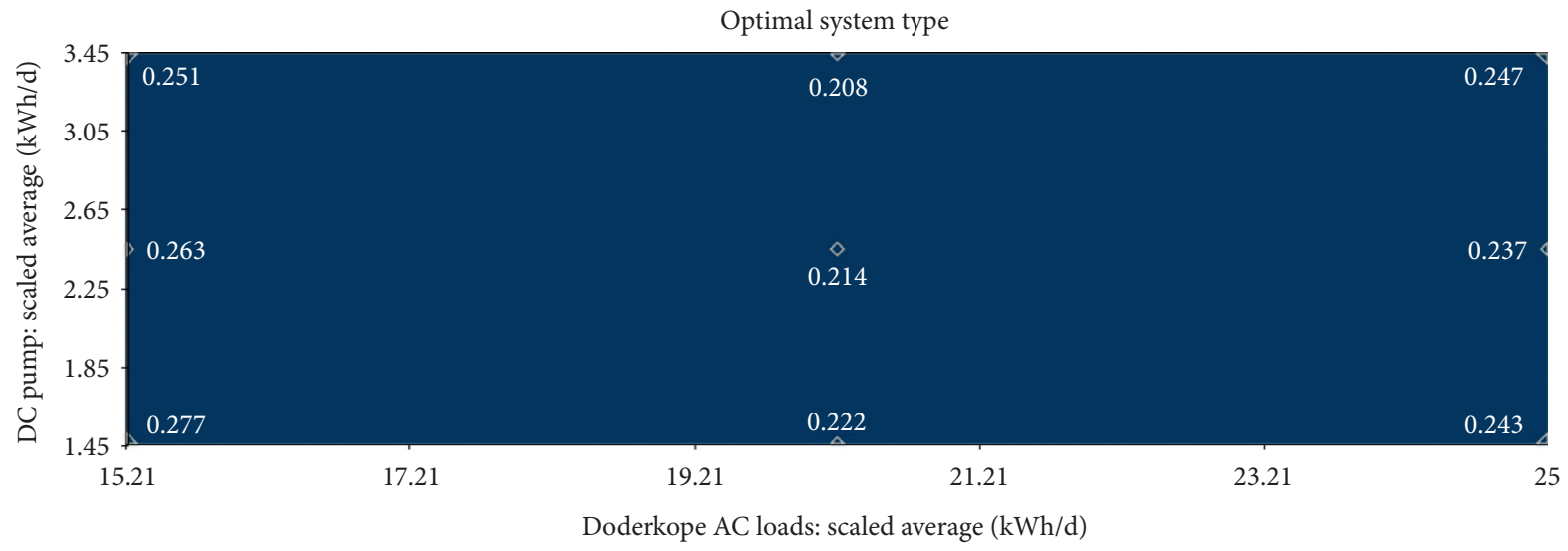

G10/Dis6.6

Figure 15: Sensitivity (COE) of HRES 2.

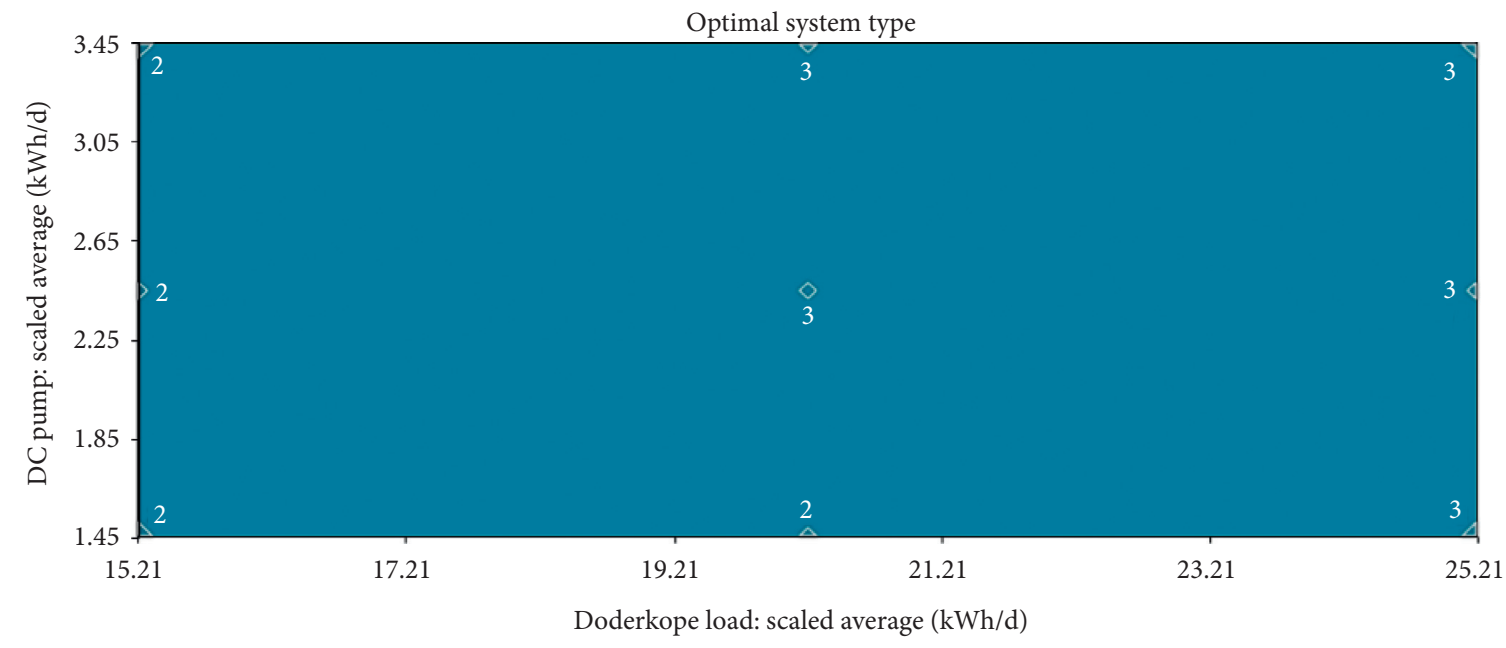

FC/G10/HTank/electrolyzer

Figure 16: Sensitivity (G10) of HRES 1.

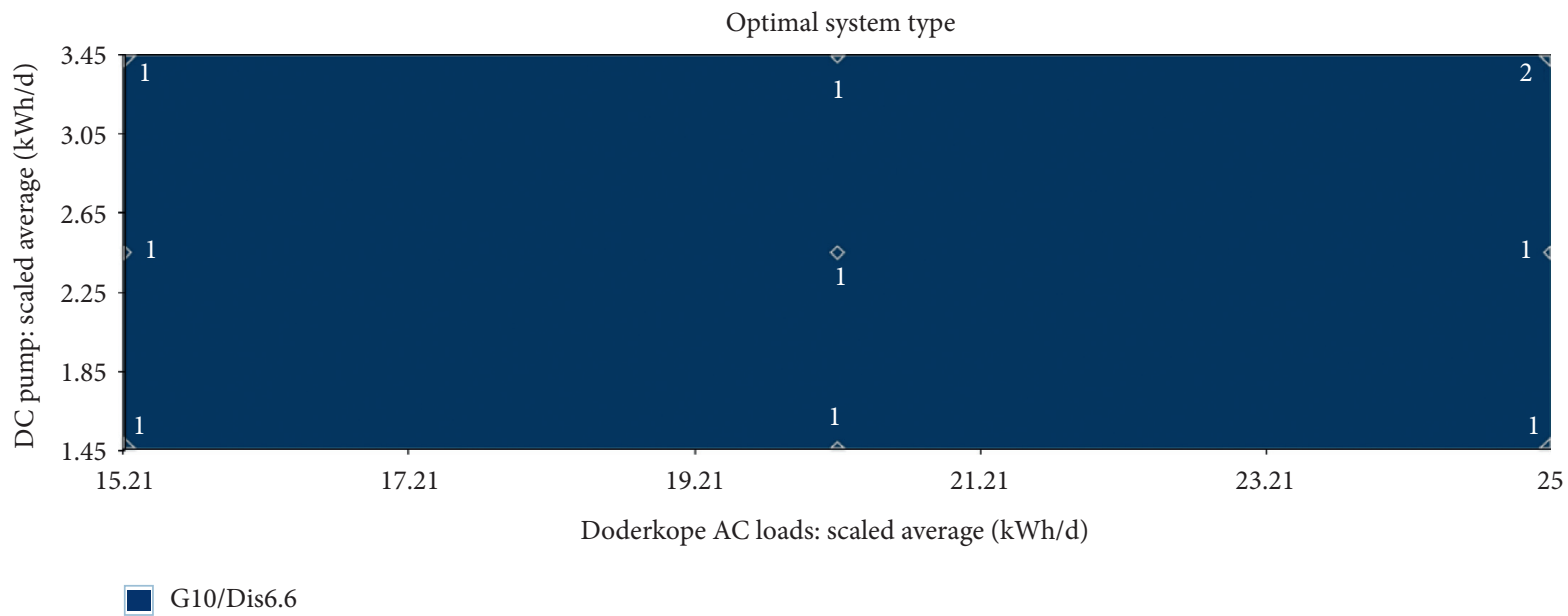

Figure 17: Sensitivity (G10) of HRES 2. 
achieved before the quantity of wind turbine finally increased.

\section{Discussion}

In this study, two different HRES, namely, wind/hydrogen fuel cell and wind/battery storage system were investigated, analyzed, and compared using HOMER Pro software to determine the optimal configuration based on net present value, cost of electricity, and amount of generated energy.

The Doderkope location in Ghana which was used for data collection and analysis recorded an annual average wind speed of $5.18 \mathrm{~m} / \mathrm{s}$ with the scaled average AC load and DC load of $15.21 \mathrm{kWh} /$ day and $1.45 \mathrm{kWh} /$ day, respectively. The optimal HRES scenario with the lowest NPC and COE is the HRES 2 with $10 \mathrm{~kW}$ wind turbine, $5 \mathrm{~kW} \mathrm{AC/DC}$ inverter, and $6.6 \mathrm{kWh}$ (10 strings size) battery capacity. It can be noticed from Table 3 that the NPC for the optimum HRES scenario is US\$ $236,876.34$ and the COE is US\$ 0.28 per $\mathrm{kWh}$. The COE obtained is comparable to that of Shiroudi et al. [7] whose HRES with battery storage was US $\$ 0.37$ per $\mathrm{kWh}$.

The total annual electricity generated is $14,739 \mathrm{kWh} / \mathrm{yr}$ compared with HRES 1 that generated $39805 \mathrm{kWh} / \mathrm{yr}$, an amount that is about 270\% the generated energy by HRES 2 . This excess electricity generated during high wind regimes would have been wasted if not reused, but in the case of HRES 2, it is used to generate and store hydrogen. As can be seen from Table 3 , the excess electricity generated yearly in HRES 2 is $8355 \mathrm{kWh} / \mathrm{yr}$ compared to HRES 1 excess electricity of $4,932 \mathrm{kWh} / \mathrm{yr}$.

Considering HRES scenario 1 on the basis of reduced excess electricity, the electrolyser produced annual hydrogen of $601 \mathrm{~kg}$ as compared with Zhao and Brouwer [34] whose $50 \mathrm{~kW}$ electrolyser produced $621 \mathrm{~kg}$ of hydrogen annually.

Comparing the battery storage in HRES 2 and FC/tank/ electrolyser storage system in HRES 1, the storage system in HRES 1 has a higher capital investment than the battery storage in HRES 2 as illustrated in Figures 8 and 9. In the NPV component cost for HRES 1, the storage system cost is $64 \%$ of the total cost of the system, whereas the battery storage in HRES 2 is $33 \%$ of the total cost of the system. These findings are normally expected because the hydrogen fuel-cell technology is a new area of research compared to the battery storage system which has well-established technology. The new technology is still going through some transformation to improve its capacity and maximize its benefits.

The objective of the sensitivity analysis was to reliably compare the two HRES scenarios and determine the one that will easily cope with increasing electric load demand. The sensitivity analysis results are shown in Figures $12-17$ on the basis of NPV, COE, and electricity generated. Despite the higher NPV and COE associated with HRES 1, results showed a reduction in NPV and COE as the annual scaled electric load increases. However, for HRES2, the NPV and COE reduced as the scaled annual electric load increased with a sudden increase in NPV and COE. Though the hydrogen fuel cell in HRES 1 in this study is not economically competitive with the battery storage, in terms of storage capacity and conversion of large excess electricity, it does provide a competitive advantage in terms of long-term storage. Hydrogen storage and transportation have some advantages that make hydrogen/fuel cell a promising technology for energy storage systems. Moreover, the hydrogen fuel-cell technology presents a smaller green house gas emission and is more environmental friendly than the battery storage system.

\section{Conclusion}

In this study, two sets of hybrid energy supplies based on RE were defined, modelled, simulated, and compared on the basis of performance parameters, namely, NPV, COE, and generated electricity. A hydrogen fuel cell and battery storage system were configured with wind turbine generator and compared. The evaluation of the two proposed HRES scenarios showed that the HRES 1 (traditional wind/battery configuration) has a clear economic advantage over the HRES 2 (wind/hydrogen fuel-cell system) for a typical ruralurban community, Doderkope in Ghana. The simulation results showed that the HRES 1 had the lowest NPV and COE along the project life span of 25 years. However, HRES 2 proved technically feasible as the hydrogen storage system converted higher percentage of excess energy into hydrogen gas for use by the fuel-cell technology to generate electricity during low wind regimes. Additionally, it extends the system's autonomy in the form of stored hydrogen, and its negligible GHG footprint can be used to reduce the total cost of the system in the form of carbon credits. Further research and technological advancement in hydrogen fuel-cell technology are necessary for their adoption as alternative energy storage system compared to traditional battery energy storage.

\section{Data Availability}

The data used to support the findings of this study are included within the article.

\section{Conflicts of Interest}

The authors declare that they have no conflicts of interest.

\section{References}

[1] IRENA, "Climate change and renewable energy: national policies and the role of communities, cities and regions (report to the G20 climate sustainability working group (CSWG))," 2019, http://www.irena.org.

[2] A. Acakpovi, M. B. Michael, N. Y. Asabere, and J. Honvo, "Exploring the fundamentals of solar photovoltaic technology and its modelling," in Renewable Energy Systems, S. A. Kale, Ed., pp. 1-282, 2017, https://mail.google.com/mail/u/0/?pli=1\%5Cn papers3://publication/uuid/D84FC782-E317-4880-B951-06972 13436E1.

[3] WWEM, "Hydrogen fuel cells companies and suppliers serving ghana," 2019, https://www.environmental-expert.com/compan ies/serving-ghana/?keyword=hydrogen+fuel+cells. 
[4] M. Baneshi and F. Hadianfard, "Techno-economic feasibility of hybrid diesel/PV/wind/battery electricity generation systems for non-residential large electricity consumers under southern Iran climate conditions," Energy Conversion and Management, vol. 127, pp. 233-244, 2016.

[5] T. Ma, H. Yang, and L. Lu, "A feasibility study of a stand-alone hybrid solar-wind-battery system for a remote island," Applied Energy, vol. 121, pp. 149-158, 2014.

[6] B. Ould Bilal, V. Sambou, P. A. Ndiaye, C. M. F. Kébé, and M. Ndongo, "Optimal design of a hybrid solar-wind-battery system using the minimization of the annualized cost system and the minimization of the loss of power supply probability (LPSP)," Renewable Energy, vol. 35, no. 10, pp. 2388-2390, 2010.

[7] A. Shiroudi, R. Rashidi, G. B. Gharehpetian, S. A. Mousavifar, and A. Akbari Foroud, "Case study: simulation and optimization of photovoltaic-wind-battery hybrid energy system in Taleghan-Iran using homer software," Journal of Renewable and Sustainable Energy, vol. 4, no. 5, Article ID 053111, 2012.

[8] M. Tahani, N. Babayan, and A. Pouyaei, "Optimization of PV/ Wind/Battery stand-alone system, using hybrid FPA/SA algorithm and CFD simulation, case study: Tehran," Energy Conversion and Management, vol. 106, pp. 644-659, 2015.

[9] C. Wang and M. H. Nehrir, "Power management of a standalone wind/photovoltaic/fuel cell energy system," IEEE Transactions on Energy Conversion, vol. 23, no. 3, pp. 957-967, 2008.

[10] D. Das, R. Esmaili, L. Xu, and D. Nichols, “An optimal design of a grid connected hybrid wind/photovoltaic/fuel cell system for distributed energy production," in Proceedings of the IECON Proceedings (Industrial Electronics Conference, pp. 2499-2504, Singapore, 2005.

[11] J. Li, W. Wei, and J. Xiang, "A simple sizing algorithm for stand-alone PV/Wind/Battery hybrid microgrids," Energies, vol. 5, no. 12, pp. 5307-5323, 2012.

[12] L. Zhang and Y. Li, "Optimal energy management of windbattery hybrid power system with two-scale dynamic programming," IEEE Transactions on Sustainable Energy, vol. 4, no. 3, pp. 765-773, 2013.

[13] M. Singh and A. Chandra, "Control of PMSG based variable speed wind-battery hybrid system in an isolated network. 2009," IEEE Power and Energy Society General Meeting, vol. 1-6, 2009.

[14] M. T. Iqbal, "Simulation of a small wind fuel cell hybrid energy system," Renewable Energy, vol. 28, no. 4, pp. 511-522, 2003.

[15] M. J. Khan and M. T. Iqbal, "Dynamic modeling and simulation of a small wind-fuel cell hybrid energy system," Renewable Energy, vol. 30, no. 3, pp. 421-439, 2005.

[16] J. Samaniego, F. Alija, S. Sanz, C. Valmaseda, and F. Frechoso, "Economic and technical analysis of a hybrid wind fuel cell energy system," Renewable Energy, vol. 33, no. 5, pp. 839-845, 2008.

[17] T. F. El-Shatter, M. N. Eskander, and M. T. El-Hagry, "Energy flow and management of a hybrid wind/PV/fuel cell generation system," Energy Conversion and Management, vol. 47, no. 9-10, pp. 1264-1280, 2006.

[18] D. B. Nelson, M. H. Nehrir, and C. Wang, "Unit sizing and cost analysis of stand-alone hybrid wind/PV/fuel cell power generation systems," Renewable Energy, vol. 31, no. 10, pp. 1641-1656, 2006.

[19] Y. Sawle, S. C. Gupta, B. A. Kumar, and W. Meng, "PV-wind hybrid system: a review with case study," Cogent Engineering, vol. 3, no. 1, Article ID 1189305, 2016.
[20] R. K. Rajkumar, V. K. Ramachandaramurthy, B. L. Yong, and D. B. Chia, "Techno-economical optimization of hybrid pv/ wind/battery system using Neuro-Fuzzy," Energy, vol. 36, no. 8, pp. 5148-5153, 2011.

[21] A. Maleki and F. Pourfayaz, "Optimal sizing of autonomous hybrid photovoltaic/wind/battery power system with LPSP technology by using evolutionary algorithms," Solar Energy, vol. 115, pp. 471-483, 2015.

[22] S. Ahmadi and S. Abdi, "Application of the Hybrid Big BangBig Crunch algorithm for optimal sizing of a stand-alone hybrid PV/wind/battery system," Solar Energy, vol. 134, pp. 366-374, 2016.

[23] P. Lilienthal and P. Gilman, "HOMER: the micropower optimization model. National renewable energy laboratory (NREL) innovation for our energy future (fact sheet)," $\mathrm{Na}$ tional Renewable Energy Laboratory, 2004.

[24] A. Acakpovi, M. B. Issah, F. X. Fifatin, and M. B. Michael, "Wind velocity extrapolation in ghana by weibull probability density function," Wind Engineering, vol. 42, no. 1, Article ID 0309524X1772320, 2017.

[25] M. Nedaei, "Wind energy potential assessment in Chalus county in Iran," International Journal of Renewable Energy Research, vol. 2, 2012.

[26] E. Holt and J. Wang, "Trends in wind speed at wind turbine height of $80 \mathrm{~m}$ over the contiguous United States using the north American regional reanalysis (NARR)," Journal of Applied Meteorology and Climatology, vol. 51, no. 12, pp. 2188-2202, 2012.

[27] J. F. Manwell, J. G. McGowan, and A. L. Rogers, "Wind energy explained: theory, design and application," in Wind Energy Explained: Theory, Design and ApplicationWiley, Hoboken, NJ, USA, 2010.

[28] Aeolos Wind Turbine, "Aeolos wind turbine company - $10 \mathrm{kw}$ wind turbine - domestic wind generator $10 \mathrm{kw}$ wind turbine manufacturers - aeolos $10 \mathrm{kw}$ turbine," 2020, https://www. windturbinestar.com/10kwh-aeolos-wind-turbine.html.

[29] A. M. Eltamaly and M. A. Mohamed, "A novel design and optimization software for autonomous PV/wind/battery hybrid power systems," Mathematical Problems in Engineering, vol. 2014, Article ID 637174, 16 pages, 2014.

[30] M. A. Mohamed, A. M. Eltamaly, and A. I. Alolah, "PSObased smart grid application for sizing and optimization of hybrid renewable energy systems," PLoS One, vol. 11, no. 8, Article ID e0159702, 2016.

[31] O. Erdinc and M. Uzunoglu, "Optimum design of hybrid renewable energy systems: overview of different approaches," Renewable and Sustainable Energy Reviews, vol. 16, no. 3, pp. 1412-1425, 2012.

[32] S. Gaddada and S. P. K. Kodicherla, "Wind energy potential and cost estimation of wind energy conversion systems (WECSs) for electricity generation in the eight selected locations of Tigray region (Ethiopia)," Renewables: Wind, Water, and Solar, vol. 3, no. 1, pp. 1-13, 2016.

[33] A. Ucar and F. Balo, "Investigation of wind characteristics and assessment of wind-generation potentiality in Uludağ-Bursa, Turkey," Applied Energy, vol. 86, no. 3, pp. 333-339, 2009.

[34] L. Zhao and J. Brouwer, "Dynamic operation and feasibility study of a self-sustainable hydrogen fueling station using renewable energy sources," International Journal of Hydrogen Energy, vol. 40, no. 10, pp. 3822-3837, 2015. 